\title{
Bioethica
}

Vol 1, No 1 (2015)

Bioethica

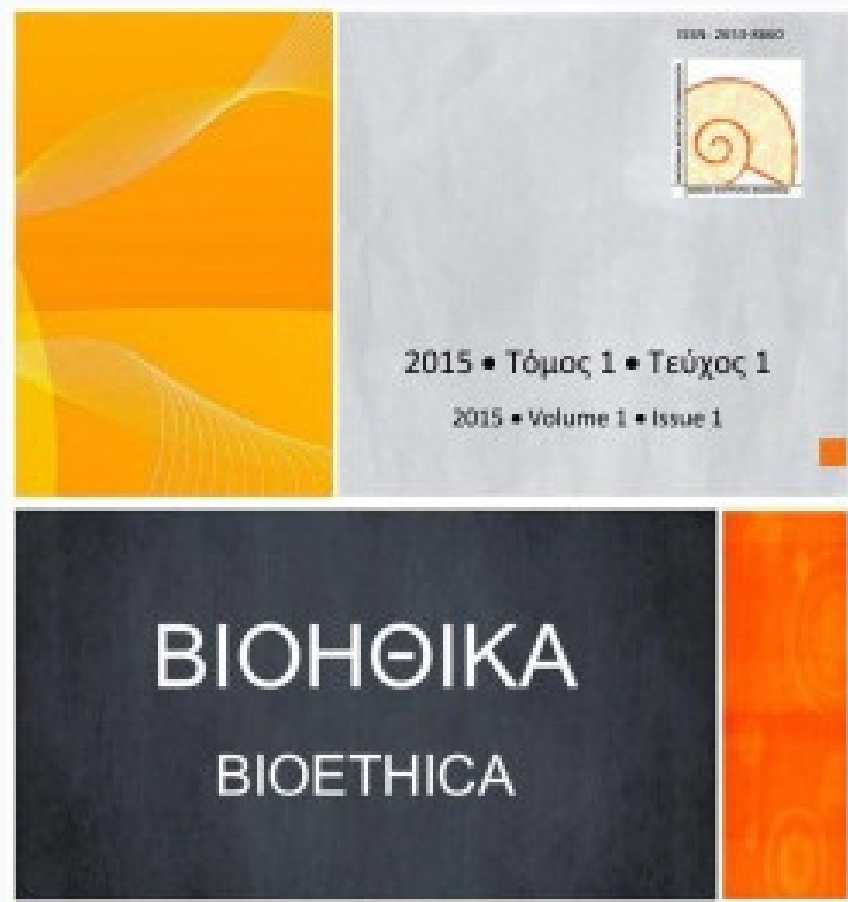

Should there be two genders? The case of intersex people

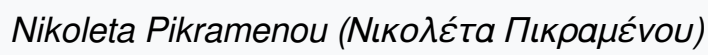

doi: $10.12681 /$ bioeth. 19563

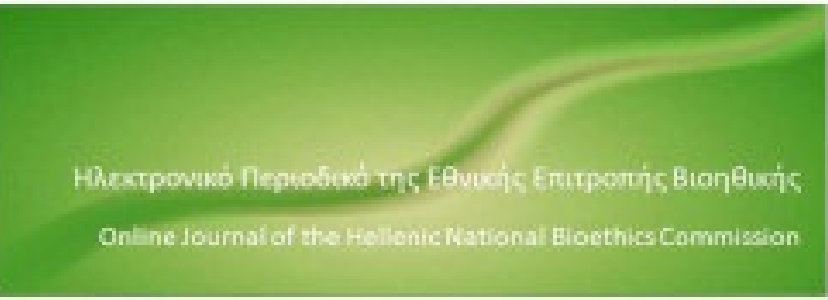

To cite this article:

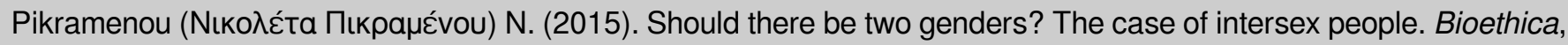
1(1), 25-31. https://doi.org/10.12681/bioeth.19563 


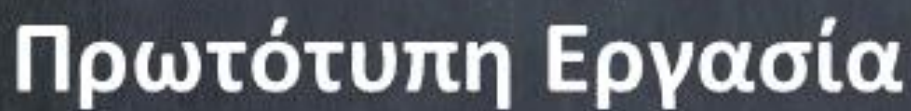

\section{Should there be two genders? The case of intersex people}

\author{
Nikoleta Pikramenou, Lawyer, MSc
}

\section{Abstract}

nicolepikram@yahoo.com

Gender refers to all those social, cultural, and psychological traits which are linked to males and females through particular social contexts. Sex makes us male or female and gender makes us masculine or feminine. However, this relatively simple distinction masks a number of problems associated with its usage. It implies that all people can be conveniently placed into unambiguous "either-or" categories.

Intersex people are born with characteristics that are in between male and female. Consequently, they often go through a lot of suffering because intersex infants are sometimes subjected to unnecessary medical or surgical treatment that is cosmetic rather that vital for health in order to fit in the gender binary model. Although at least one in every thousand people is born intersex, many countries do not acknowledge their existence. Their rights are also ignored because they don't fit into standard social and medical models.

In this article, I will examine the negative effects of this gender binary distinction and justify my arguments by using the example of intersex people.

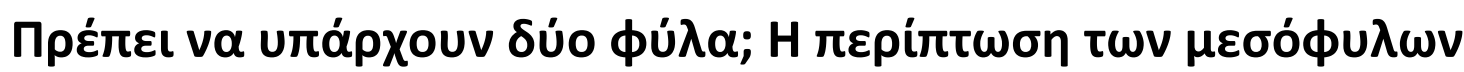

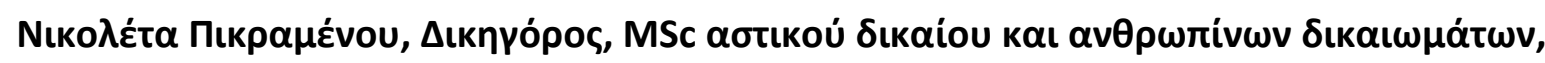

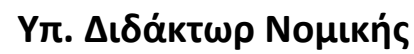

\section{Пері́ $\eta \psi \eta$}

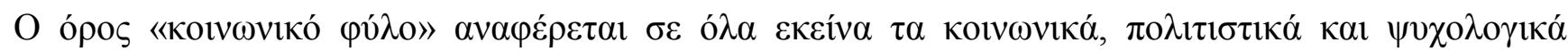

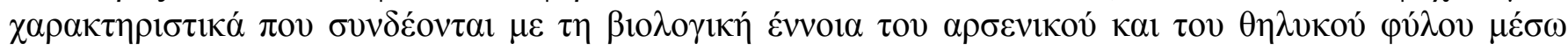

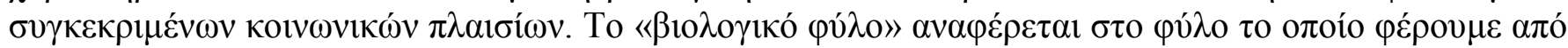

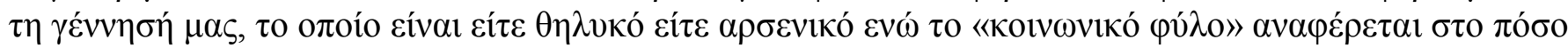

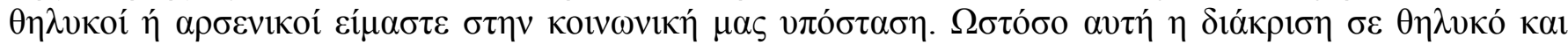

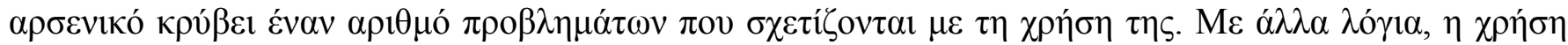

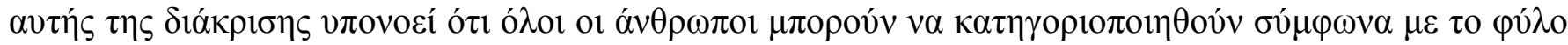

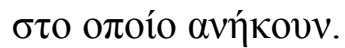

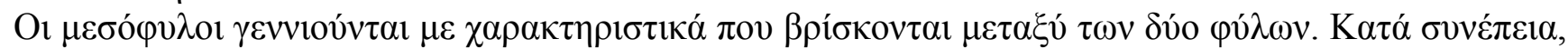

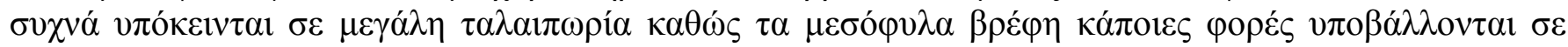

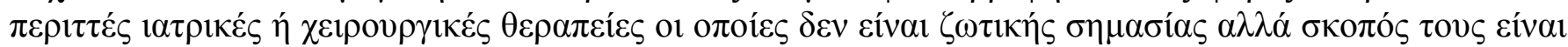

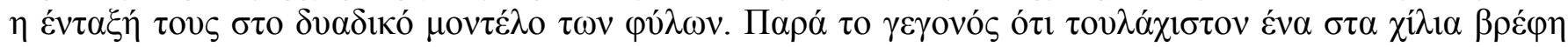

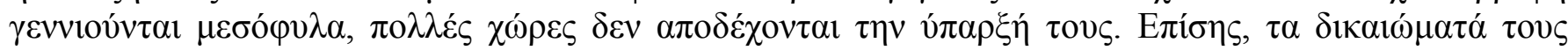

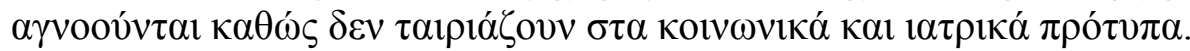

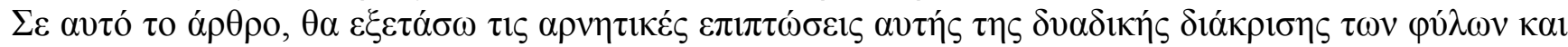

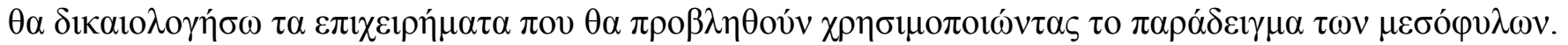


Gender refers to those social, cultural, and psychological traits linked to males and females through particular social contexts. ${ }^{1}$.Gender makes us masculine or feminine whereas sex makes us males and females. ${ }^{2}$ Symbolic interactionists contend that concepts used to collectively categorise people such as race, ethnicity, and gender do not exist objectively but emerge through a socially constructed process. ${ }^{3}$

Intersexuality is a condition that reflects a biological variation. To better explain this, we can compare the sex spectrum to the color spectrum. There's no question that in nature there are different wavelengths that translate into colors most people see as red, blue, orange, yellow. But the decision to distinguish, between orange and red-orange is made only when we need it. Sometimes social necessity leads us to make color distinctions that otherwise would seem incorrect or irrational. In the same way, nature presents us with different sex anatomy spectrums. $^{4}$ But in human cultures, gender categories get simplified only into male and female.

Nature doesn't decide where the category of "male" or "female" ends and the category of "intersex" begins or vice versa. Humans decide 5 . Humans decide how unusual a combination of parts can be. Our societies are based on norms derived from the idea of the binary gender model. Consequently, people who do not easily fit in these norms, such as intersex people, encounter numerous difficulties, both on the practical level of everyday life and on a legal level. $^{6}$

In this article, the negative effects of this binary distinction will be examined by using the example of intersex people.

\footnotetext{
${ }^{11}$ Lindsey, 2011, p. 4.

${ }^{2}$ Idem.

${ }^{3}$ Idem, p. 10.

${ }^{4}$ ISNA, "What is intersex?".

5 Idem.

${ }^{6}$ Agius and Tobler, 2011, p. 9.
}

\section{What is intersex?}

"Intersex" ${ }^{7}$ is a general term used for a variety of conditions in which a person is born with a reproductive or sexual anatomy that doesn't seem to fit in the typical definitions of female or male. For example, a person might be born appearing to be female on the outside, but having, mostly male-typical anatomy on the inside. Or a person may be born with genitals that seem to be inbetween the usual male and female types. ${ }^{8}$ However, intersex anatomy doesn't always show up at birth. Sometimes a person doesn't have intersex anatomy until she or he reaches the age of puberty, or finds himself/herself an infertile adult, or dies of old age and is autopsied. ${ }^{9}$

At this point, it is essential to make the distinction between intersex people and trans people as these terms are often confused. The term "trans" 10 includes those people who have a gender identity ${ }^{11}$ that is different from the $\operatorname{sex}^{12}$ they were assigned at birth. ${ }^{13}$

On the other hand, intersex people differ from trans people as their status is not gender-related but instead relates mostly to their biological makeup ${ }^{14}$. Anne-Fausto Strerling conducted an assessment with Brown University undergraduates and estimated intersexual birthrates to be about $1.7 \% .^{15}$

Above all, what happens when an intersex baby is born? Sometimes, surgery is performed at birth. However, some say that surgical

\footnotetext{
7 In the past, intersex people used to be called "hermaphrodites" but this term in our days is considered as stigmatising and misleading.

${ }^{8}$ ISNA, "What is intersex?".

${ }^{9}$ Idem.

${ }^{10}$ The umbrella term "trans" includes, but is not limited to, people who identify themselves as transsexual, transgender, transvestite, adrogyne, polygender, genderqueer, agender, gender variant.

11 Gender identity refers to each person's deeply felt internal and individual experience of gender, which may or may not correspond with the sex assigned at birth.

12 Sex refers to biological makeup such as primary and secondary sexual characteristics, genes and hormones.

${ }_{13}$ Agius and Tobler, 2011, p. 12.

${ }^{14}$ Idem.

${ }^{15}$ Fausto-Sterling, 2000, p. 51.
} 
treatment is socially motivated and ethically questionable.

\section{Trying to "fix" intersex people}

Especially during earlier times, the choice of what gender the child would be given the ability to emulate was up to the doctors. At that time, doctors believed that the gender they were assigning the intersex child was the gender "nature" intended for the child to have and that it was up to the parents to "nurture" the child in such a way that he/she would behave like that gender. However, the case of David Reimer, also known as the John/ Joan case proves them wrong.

David Reimer was not an intersex baby. He had a minor medical problem called phimosis and a doctor decided to treat the problem with circumcision. The doctor chose to use an electric cautery machine but the machine did not function well and accidentally burned off all of David's penis. ${ }^{16}$ David's parents agreed to have him "sex reassigned" and made him into a girl, via the system "Money advocated for intersex children". ${ }^{17}$ As soon as David found out what happened to him, he reassumed the social identity of a boy. ${ }^{18}$ Although David was not an intersex child, the case indicates that a decision of doctors or parents to assign a child a sex can have disastrous consequences. It shows the power of nature and why it should always be considered in the case of intersex infants. It also

\footnotetext{
${ }^{16}$ Woo, "David Reimer, 38, After Botched Surgery, He was Raised as a Girl in Gender Experiment".

${ }^{17}$ Dr. Money was a psychologist specializing in research into sexual identity and biology of gender. Money had developed the theory of "gender neutrality". He believed that when a child is born, for the first two years they are "gender neutral". This is because he believed that biology does not determine the phenotype of a child but their gender can be controlled by environmental factors. In other words, a baby born as a boy can be brought up as a girl, and will act and "be" a girl (AS Revision 101, Money 1975).

${ }^{18}$ ISNA, "Who was David Reimer?".
}

raises questions about whether a decision to assign a sex can be made too early. ${ }^{19}$

Money's theory was also criticised by Cheryl Chase who experienced a painful intersex history. Cheryl was born with ambiguous genitals. In the beginning, a male birth certificate was completed for her and her parents began raising her as a boy. ${ }^{20}$ Later, the doctors judged that her genital appendage was inadequate as a penis so her anatomy was relabeled and following doctor's orders her parents changed her name, moved to another place and started raising her as a girl. ${ }^{21}$ For many years, Chase was kept in the dark about her early medical treatment: she underwent a mysterious abdominal surgery at the age of eight, followed by annual pediatric endocrinological check-ups until the age of twelve, when she began menstruating. $^{22}$ She was also seen by a psychiatrist due to her disruptive behavior. At nineteen she began seeking information about her medical story. It was after much perseverance that she found out that she has been declared a boy at birth but this had been reversed. $^{23}$

In 2013, the United Nations (UN) Special Rapporteur on torture and other cruel, inhuman or degrading treatment or punishment condemned the practice of surgically altering children born with ambiguous genitalia. ${ }^{24}$ In particular, he stated that: "Children who are born with atypical sex characteristics are often subject to irreversible sex assignment, involuntary sterilisation, involuntary genital normalizing surgery, performed without their informed consent, or that of their parents, 'in an attempt to fix their sex', leaving them with permanent,

\footnotetext{
${ }^{19}$ Australian Human Rights Commission (report), 2009, p. 7.

${ }^{20}$ Chase, 1998, p. 192.

21 Idem.

${ }^{22}$ Rosario, 2006, p. 93.

${ }^{23}$ Idem.

24 UN, General Assembly, "Report of the Special Rapporteur on torture and other cruel, inhuman or degrading treatment or punishment, Juan E. Mendez", A/HRC/22/53 (1 February 2013) available from http://www.ohchr.org/Documents/HRBodies/HRCouncil/R egularSession/Session22/A.HRC.22.53_English.pdf.
} 
irreversible infertility and causing severe mental suffering". 25

Accordingly, surgical interventions on intersex infants should be considered as unnecessary. Surgical interventions are performed on infants based on the claim that intersex anatomies represent a crisis that must be resolved immediately through surgery. ${ }^{26}$ Instead, the evidence have shown that in almost all cases, genital surgery can be safely delayed until the person involved is able to participate in the decision. ${ }^{27}$

\section{Intersex people and the "third gender"}

At present the law divides people into the categories of male and female, albeit nowhere in legislation are these terms defined. Nor is it clearly explained whether an individual must be male in order to be legally recognized as a man. ${ }^{28}$

Likewise, in most societies, people believe there are only two sexes, male and female. However, there are places on other parts of the world where gender pluralism exists. ${ }^{29}$ A typical example is the Hijras ${ }^{30}$ who mostly live in India and they are a group of people who belong to the "third gender". Hijras are not transsexuals as they do not see themselves as women trapped in men's bodies but they see themselves as an inbetween who belongs to the "third gender". 31 Accordingly, the term "third gender" is a general term that describes individuals who cannot be categorized as either man or woman.

On April 2014, India's Supreme Court in a landmark ruling recognized Hijras as a third

\footnotetext{
${ }^{25}$ Idem.

${ }^{26}$ Lear, 2007, p. 53.

${ }^{27}$ Idem.

${ }^{28}$ Mhuithile, 2013, p.133.

29 Anthropology\& The human condition, "The Third Gender: Hijras in India".

30 Hijras could be translated into "trans people". Nonetheless, it should be mentioned that Hijras in India have played a prominent role in Indian culture during the ancient years and they were once treated with great respect.

${ }^{31}$ Idem.
}

gender. "It is the right of every human being to choose their gender", it is said in granting rights to those who identify themselves as neither male nor female. ${ }^{32}$ Still, this is not the first time that the "third gender" is legally recognized.

In 2013, the Australian government adopted national guidelines that allow individuals to choose a gender other than male or female on personal documents. In particular, where sex and/or gender information is collected and recorded in a personal record, individuals are given the option to select $\mathrm{M}$ for male, $\mathrm{F}$ for female and $\mathrm{X}$ for Indeterminate/ Intersex/ Unspecified. ${ }^{33}$

In the European context, in 2013 Germany became the first country to allow the parents of babies without "clear gender-determining physical characteristics" to register them not as male or female, but to choose a third blank box instead. ${ }^{34}$ This new policy was an attempt to remedy the previous horribly difficult situation for German parents who had just a week's time to decide whether their intersex children were male or female and register them appropriately. ${ }^{35}$ Nevertheless, activists promoting the rights of intersex people are unsatisfied with the law as the "blank box" choice does not create a third gender. They said they hoped that a third gender option would open the door to broader changes limiting genital surgery on newborns with both male and female characteristics. ${ }^{36}$

\section{Rethinking the binary gender model}

Modern scholars have criticized the standard of binary of gender for several reasons such as the inclusion of intersex individuals and the trust our society gives doctors and scientists.

Anne Fausto-Sterling criticises the standard model of sex and gender by explaining how

\footnotetext{
${ }^{32}$ BBC news, "India court recognizes transgender people".

33 Zara, "Intersex Austalia: Third Gender Allowed on Personal Documents in Addition to Male and Female".

${ }^{34}$ Nandi, "Germany got it right by offering a third gender option on birth certificates".

${ }^{35}$ Idem.

${ }^{36}$ Idem.
} 
intersex people are neither male nor female and as a result they do not fit in the sex binary. She analyses how people put a great deal of trust in doctors because they are seen as the experts and those who decide what nature tells us. ${ }^{37}$ Moreover, as our society is based on the classification of people according to gender, anyone who falls outside the norm is seen as abnormal or needing to be fixed.

By the same token, Judith Butler claims that notions such as skin color, sexual orientation and birth have been some of the concepts used to classify someone as human while at the same time they prevent others from being approached as such. ${ }^{38}$ If someone is unable to be framed within the normative markers of identity that are used to approach and categorize humans, he/she is not only queer but he also runs the risk of facing violence or of living an unbearable life. ${ }^{39}$

All these thoughts make us reconsider the binary gender model and the level of gender stereotypes that exist within it. To tell the truth, this binary model could be seen as one of the sources of multiple human rights issues in both national and international levels.

This norm disadvantages and marginalizes all persons whose sex, gender identity and gender expression do not meet social expectations. ${ }^{40}$ In addition to the disadvantage emanating out of the binary gender model, intersex people are very often subjected to interphobia. Social interphobia is manifested in the forms of physical and other forms of violence, hate speech, discrimination, threats, marginalization, social exclusion, ridicule and insults. ${ }^{41}$

\section{Should there be two genders?}

It is clear that it is widely accepted that gender is not an identity. Instead, it is an institutionalized system of social practices for dividing people in two significantly different

\footnotetext{
${ }^{37}$ Fausto-Sterling, 2000, pp. 48-115.

${ }^{38}$ Butler, 2004, pp. 17-40.

${ }^{39}$ Idem.

${ }^{40}$ Agius and Tobler, 2011, p. 13

${ }^{41}$ Idem.
}

categories and for organizing relations of inequality around that difference. ${ }^{42}$

The case of intersex people shows us that everyone should be given the opportunity to choose how he or she could live, and should not be forced into a life of turmoil because of some clinical decision that was made on his or her behalf $^{43}$ in order to be socially acceptable. Gender-assigning surgery should involve much more input from the children themselves, either through voiced opinions or observations of actions. $^{44}$

However, it should be admitted that gender categorization is not going to disappear. It is too fundamentally entwined in the organization of interaction and the establishment of socially meaningful identities for one's self and others. ${ }^{45}$ It is possible though, to minimize the degree of difference and inequality the gender system involves. For instance, concerning the case of intersex people, in the future, as with race and religion, sex or gender should not be a category on birth certificates or identification documents for anybody.

After all, we should bear in mind what Sarah Graham, an intersex woman and counselor, said on BBC channel: "This pink and blue thing is nonsense. The human heart is the most important organ not what goes on "down there".

\footnotetext{
${ }^{42}$ Ridgeway and Coller, 2000, p. 110.

${ }^{43}$ Switzer, 2005, p. 73.

${ }^{44}$ Idem.

${ }^{45}$ Ridgeway and Coller, 2000, p. 119.
} 


\section{References}

Books

Butler Judith, "Undoing Gender", Routledge New York and London, 2004, pp. 17-40.

Fausto-Sterling Anne, "Sexing the Body: gender politics and the construction of sexuality", New York: Basic Books, 2000, pp. 45-115.

Lear Jonathan, "Unnecessary surgery on intersex infants: Problems of theory become problems in practice", Master's Thesis in Applied Ethics, Centre for Applied Ethics, Linkopings University, 2007, pp. 53-55.

Mhuirthile $\mathrm{Ni}$ Tania, "Legal Recognitions of Preferred Gender Identity in Ireland: An analysis of Proposed Legislation", 2013, Chapter 5, p. 133.

Ridgeway Cecilia and Correll Shelley, "Limiting inequality through interaction: the End(s) of Gender", Symposium, Stanford University, 2000, pp. 110-119.

\section{$\underline{\text { Articles }}$}

BBC News, "India court recognizes transgender people as third gender", http://www.bbc.com/news/world-asia-india27031180 (last accessed on 7 October 2014).

Chase Cheryl, "Hermaphrodites with attitude: Mapping the emergence of intersex political activism", Journal of Lesbian and Gay studies, Vol.4 No.2, 1998, pp.189-211.

Nandi Jacinta, "Germany got it right by offering a third gender option on birth certificates" on The Guardian, http://www.theguardian.com/commentisfree/2 013/nov/10/germany-third-gender-birthcertificate (last accessed on 8 October 2014).

Rosario Vermon A., "An Interview with Cheryl Chase", Journal of Gay\& Lesbian Psychotherapy Vol. 10 No 2, 2006, p. 93-104.

Switzer Latesha, "Can Surgery For Intersex Babies be Justified?", The York Scholar Vol.2, 2005, pp. 67-74.

Wilson Gina, "Equal Rights for Intersex People", The Equal Rights Review, vol.10, 2013, pp.133-136.
Woo Elaine, "David Reimer, 38, After Botched Surgery, He was Raised as a Girl in Gender Experiment", Los Angeles Times, 2004, http://articles.latimes.com/2004/may/13/local/ me-reimer13 (last accessed on 7 October 2014).

Zara Christopher, "Intersex Austalia: Third Gender Allowed on Personal Documents in Addition to Male and Female" on International Business Times, http://www.ibtimes.com/intersex-australiathird-gender-allowed-personal-documentsaddition-male-female-1307843 (last accessed on 8 October 2014).

\section{$\underline{\text { Reports }}$}

Agius Silvan, Tobler Christa, "Trans and intersex people, Discrimination on the grounds of sex, gender identity and gender expression", European Commission report, 2011, p.1-108.

Australian Human Rights Commission, "Surgery on intersex infants and human rights", 2009, pp.1-10.

UN, General Assembly, "Report of the Special Rapporteur on torture and other cruel, inhuman or degrading treatment or punishment, Juan E. Mendez”, A/HRC/22/53 (1 February 2013) available from http://www.ohchr.org/Documents/HRBodies/ HRCouncil/RegularSession/Session22/A.HR C.22.53_English.pdf (last accessed on 7 October 2014).

\section{$\underline{\text { Websites }}$}

Anthropology\& The human condition, "The Third Gender: Hijras in India" http://sc2218.wikifoundry.com/page/The+Thi rd+Gender\%3A+Hijras+In+India (last accessed on 8 October 2014).

AS Revision 101, "Money (1975)" https://aspsychology101.files.wordpress.com/ 2009/09/4-5-money-1975.pdf (last accessed on 4 October 2014). 
BBC News, "Intersex woman: This pink and blue thing is nonsense", http://www.bbc.co.uk/news/world-europe24776168 (last accessed on 9 October 2014).

Fausto-Sterling "Gender" http://www.annefaustosterling.com/fields-ofinquiry/gender/ (last accessed on 5 October 2014). 